\title{
ANALISIS KELAYAKAN INVESTASI PENGEMBANGAN PERUMAHAN SUBSIDI DI KABUPATEN TANGERANG
}

\author{
Darryl Arlen Hartanu \\ Program Studi Magister Manajemen Universitas Tarumanagara \\ darryl.hartanu@gmail.com \\ Carunia Mulya Firdausy \\ Program Studi Magister Manajemen Universitas Tarumanagara
}

\begin{abstract}
Up until now, housing investment is still interesting because the demand for housing remains high. Developers are interested to investing in the house sector because of its promising profits. However, it still needs the investment analysis to minimize the risks. Most developers only calculate investment costs compared to the sales plan. The time value of money is often not calculated eventhough costs in the housing sector investments often require many years. This is a feasibilty study based on a house development project in Tangerang Regency, which developed by PT. TCM. The developer was willing to provide the necessary data for this study including interview such as house design, siteplan, and financial data. From the project's financial data, we built the cash flow projection and analyzed the investment using Net Present Value (NPV), Internal Rate of Return (IRR), Profitability Index (PI) methods and to find the project Payback Period (PP). The results of this study indicate that the project is feasible to be developed. The result of the analyze showed NPV scored positive to value of Rp 12.061.187.000,- ; IRR is worth $24,58 \%$ > interest rate of $10 \%$, IP worth 1,79>1, for payback period is reached after 3 years and 135 days.. Thus the housing developments planning by PT. TCM, in Tangerang Regency is worth to be implemented.
\end{abstract}

Keywords : Feasibility study, investment, Net Present Value, Internal Rate of Return, Profitability Index, Payback Period

\section{PENDAHULUAN}

Lingkungan usaha mengalami perubahan yang sangat cepat. Demikian pula dengan perubahan lingkungan usaha di dalam industri properti yang sangat dipengaruhi oleh salah satu faktor utama yaitu kondisi perekonomian negara. Dinamika di dalam industri properti dapat digambarkan sebagai suatu siklus yang mengalami kenaikan dan penurunan. Siklus industri properti seperti yang dipaparkan di atas, tentunya menjadi salah satu pertimbangan bagi investor dan pengembang perumahan sebelum mengambil keputusan untuk menginvestasikan uangnya. Salah satu pengembang perumahan RS (Rumah Sederhana) dan RSS (Rumah Sangat Sederhana) di Indonesia, PT. TCM pada dasarnya juga memperhatikan kondisi properti yang berlangsung di Indonesia. Sebagai perusahaan yang sudah lebih dari sepuluh tahun berkecimpung di bisnis properti, PT. TCM memiliki strateginya sendiri menghadapi kondisi iklim properti yang berubah-ubah atau siklus pasar properti yang terjadi.

PT.TCM sendiri memiliki lahan seluas 5 hektar di Desa Rajeg Mulya, Kecamatan Rajeg, Kabupaten Tangerang yang sedang dikembangkan untuk perumahan berkelas RS (Rumah Sederhana). PT. TCM tentu sudah memiliki studi kelayakan sendiri dalam menentukan setiap investasi yang dilakukan. Dalam studi kelayakan yang dilakukan, berbagai aspek penting telah dikaji sebelumnya yaitu aspek pasar, aspek teknis / perencanaan, aspek manajemen, 
serta aspek finansial. Dan tentunya kajian berbagai aspek tersebut sudah dilakukan dalam investasi perumahan di Desa Rajeg Mulya ini.

PT. TCM melakukan kajian aspek finansial secara sederhana dengan hanya memperhitungkan dan mengestimasikan biaya (cost), beban (expense) dan pendapatan dari penjualan (income). Sedangkan dalam melakukan kajian aspek finansial, perlu juga diperhitungkan berbagai faktor penting lain seperti proyeksi laba dan proyeksi keuangan lain untuk menghasilkan analisis keuangan yang baik. Analisis keuangan yang baik perlu dilakukan agar bukan hanya nilai profit yang dapat diketahui dengan pasti, namun investor dalam hal ini pengembang juga mengetahui nilai investasi, waktu pengembalian, dan nilai keuangan lain yang tentunya menjadi pertimbangan dalam mengambil keputusan dalam berinvestasi.

Dalam studi ini, akan dianalisis bagaimana kelayakan investasi yang dilakukan PT. TCM dengan mengembangkan perumahan RS. Dengan menilai investasi untuk perumahan ini, diharapkan dapat menjadi pedoman rujukan bagi pengembangan di kawasan lain di sekitarnya baik oleh PT. TCM sendiri maupun pengembang lain.

\section{METODE PENELITIAN}

Penelitian terhadap proyek pembangunan perumahan RS (Rumah Sederhana) yang sedang dilakukan oleh PT. TCM merupakan jenis penelitian terapan (applied research) yang bersifat kuantitatif yaitu penelitian dengan pendekatan angka-angka, mulai dari pengumpulan data, penafsiran terhadap data tersebut, serta penampilan dari hasilnya.

Penelitian ini dilakukan pada periode Juli 2017 sampai dengan Oktober 2017 dengan sumber data primer yang diperoleh dengan metode interview narasumber staff keungan PT. TCM dan tinjauan langsung lapangan ke lokasi rencana pembangunan perumahan subsidi oleh PT. TCM. Sedangakan data sekunder didapat dari tinjauan pustaka berbagai publikasi, buku, dan internet.

\section{Penilaian Kelayakan Investasi}

Pada umumnya terdapat empat metode yang dapat dipertimbangkan untuk dipakai dalam penilaian aliran kas dari suatu investasi. Studi kelayakan terhadap aspek keuangan perlu menganalisi bagaimana prakiraan aliran kas akan terjadi. Pada umumnya ada empat metode yang biasa dipertimbangkan untuk dipakai dalam penilaian aliran ka dari suatu investasi, yaitu Payback Period, Net Present Value, Internal Rate of Return, dan Profitability Index.

\section{- Net Present Value (NPV)}

Net Present Value adalah selisih antara Present Value dari investasi dengan nilai sekarang dari penerimaan kas bersih (aliran kas operasional maupun aliran kas terminal) di masa yang akan datang. Untuk menghitung nilai sekarang perlu ditentukan tingkat bunga yang relevan.

Persamaan :

$$
N P V=\sum_{\mathrm{t}=1}^{\mathrm{n}} \frac{C F_{t}}{(1+K)^{t}}-I_{0}
$$

$\mathrm{CFt}=$ aliran kas pertahun pada periode $\mathrm{t}$

$\mathrm{I} 0=$ investasi awal pada tahun 0

$\mathrm{K}=$ suku bunga (discount rate)

$\mathrm{t}=$ waktu

Kriteria penilaian:

a. Jika NPV > 0, maka usulan investasi diterima

b. Jika NPV $<0$, maka usulan proyek ditolak 
c. Jika NPV $=0$, nilai perusahaan tetap walau usulan proyek diterima ataupun ditolak

\section{- Profitability Index (PI)}

Penggunaan analisis profitability index (PI) adalah dengan menghitung melalui perbandingan antara nilai sekarang (present value) dari rencana penerimaan-penerimaan kas bersih di masa yang akan datang dengan nilai sekarang (present value) dari investasi yang telah dilaksanakan. Jadi, profitability index dapat dihitung dengan membandingkan antara $P V$ kas masuk dengan $P V$ kas keluar.

Rumus:

$P I=(P V$ kas masuk $) /(P V$ kas keluar $)$

Kriteria penilaian:

1. Jika PI $>1$, maka usulan proyek dikatakan menguntungkan.

2. Jika PI $<1$, maka usulan proyek tidak menguntungkan

Kriteria ini erat hubungannya dengan kriteria $N P V$, di mana jika $N P V$ suatu proyek dikatakan layak $(N P V>0)$ maka menurut $P I$ juga layak $(P I>1)$ karena keduanya menggunakan variabel yang sama.

\section{- Internal Rate of Return (IRR)}

Metode Internal Rate of Return (IRR) digunakan untuk mencari tingkat bunga yang menyamakan nilai sekarang dari arus kas yang diharapkan di masa datang, atau penerimaan kas, dengan pengeluaran investasi awal.

Rumus yang digunakan sebagai berikut:

$\mathrm{t}=$ tahun $\mathrm{ke}$

$$
I_{0}=\sum_{t=1}^{n} \frac{C F_{t}}{(1+I R R)^{t}}
$$

$\mathrm{n}=$ jumlah tahun

$\mathrm{I} 0$ = nilai investasi awal

$\mathrm{CF}=$ arus kas bersih

$I R R=$ tingkat bunga yang dicari harganya

Nilai IRR dapat dicari dengan coba-coba (trial and error).

Kriteria penilaian :

Jika IRR yang didapat ternyata lebih besar dari rate of return yang ditentukan maka investasi dapat diterima.

Rumus IRR untuk Interpolasi adalah sebagai berikut:

$I R R=(P 1-C 1)+(p 2-p 1)$

$(p 2-p 1)$

Dimana P1 = tingkat bunga ke 1

$\mathrm{P} 2$ = tingkat bunga ke 2

$\mathrm{C} 1=$ net present value dari hasil internal rate ke-1

$\mathrm{C} 2$ = net present value dari hasil internal rate ke-2

Kriteria diterima atau ditolaknya suatu usulan rencana investasi dinyatakan sebagai berikut:

a. $I R R>$ required rate of return, diterima

b. $I R R>$ required rate of return, ditolak

\section{- Payback Period (PP)}

Payback Period adalah suatu periode yang diperlukan untuk menutup kembali pengeluaran investasi (initial cash investment) dengan menggunakan aliran kas.

Payback Period $=($ Nilai Investasi $) /($ Kas Masuk Bersih $)$

Kriteria Penilaian : 
a. Jika payback period lebih pendek waktunya dari maximum payback period-nya maka usulan investasi dapat diterima.

b. Jika payback period lebih panjang dari waktunya dari maximum payback period-nya maka usulan investasi tidak dapat diterima.

\section{HASIL DAN PEMBAHASAN}

\section{Gambaran Umum Proyek Pembangunan Rumah Subsidi}

Lokasi dari objek penelitian yaitu proyek pembangunan Perumahan Cluster New Rajeg City adalah di Desa Rajeg Mulya, Kecamatan Rajeg, Kabupaten Tangerang, Banten. Kawasan Rajeg ini merupakan kawasan pemukiman yang sedang berkembang pesat di barat Kabupaten Tangerang. Didukung dengan infrastruktur yang baik dan memiliki daearah sekitar yang merupakan kawasan industri, Kecamatan Rajeg dipilih menjadi lokasi pengembangan proyek perumahan Cluster New Rajeg City.

Setelah lokasi, konsep dan fasilitas perumahan juga menjadi nilai jual yang selalu diperhitungkan pembeli. Dengan luas area $54.693 \mathrm{~m} 2$ dan rencana jumlah hunian rencana sebanyak 503 unit, Cluster New Rajeg City memiliki fasilitas-fasilitas penunjang yaitu sistem satu gerbang (cluster), jalan lingkungan paving block, taman dan children play ground, balai warga, mushola, serta jogging track.

Ditinjau dari segi demografi, Kabupaten Tangerang memiliki pertumbuhan penduduk terbesar kedua setelah Kota Tangerang Selatan pada tahun 2016. Laju pertumbuhan penduduk Kabupaten Tangerang yang relatif tinggi yaitu sebesar 3,17 \% pada tahun 2016. Dengan komposisi penduduk yaitu terdiri dari penduduk Tangerang asli dan bercampur dengan migran (pendatang) yang bekerja di pabrik pada kawasan industri yang berada di Kabupaten Tangerang.

Ditinjau dari segi ekonomi, posisi Kabupaten Tangerang sebagai daerah penyanggah DKI Jakarta menjadi faktor penyebab kondisi ekonomi daerah ini juga sangat tergantung pada kondisi ekonomi secara nasional. Dua faktor penting yang paling menjadi indikator ekonomi nasional Indonesia adalah tingkat suku bunga dan inflasi. BI reverse repo rate sudah mengalami penurunan cukup signifikan dari 5,5 persen di Mei 2016 menjadi 4,25 persen di September 2017. Sedangkan lebih spesifik, kondisi ekonomi Kabupaten Tangerang dilihat dari laju pertumbuhan Produk Domestik Regional Bruto (PDRB) selama 3 tahun terakhir cenderung stabil di kisaran 5,3\%.

\section{Tinjauan dari Aspek Pasar}

Berdasarkan lokasi dan produk penjualannya, maka beberapa perumahan yang menjadi competitor langsung dari proyek pembangunan Perumahan Cluster New Rajeg City saat ini yaitu Neo Rajeg City oleh PT. Yuliartha Bangun Persada sebanyak 80 unit, Rajeg Mulya Residence (tahap 4) oleh PT. Putra Perkasa sebanyak 200 unit, Rajeg Gadeniaoleh PT Sari Multigriya Sentosa seluas 20 hektar, Griya Artha Rajeg oleh PT. Padma Warna Artha sebanyak 495 unit, dan Pondok Permata Rajeg oleh PT. Shinta Alam Abadi sebanyak 85 unit. Berdasarkan competitor-competitor tersebut, terlihat developer-developer kecil dan menengah bersaing dalam memperebutkan pasar. Sebagai kawasan perumahan dengan unit rumah sederhana yang termasuk dalam rumah bersubsidi, maka segmen pasar Perumahan Cluster New Rajeg City adalah kelompok masyarakat berpenghasilan rendah (MBR).

Untuk mendukung penjualan, berbagai kegiatan promosi akan yang dilakukan PT. TCM melalui media yang tersedia. Metode promosi yang akan dilakukan PT. TCM dalam memasarkan produk Cluster New Rajeg City yaitu penyebaran brosur, pemasangan spanduk, baliho, dan umbul-umbul, mengikuti event dan pameran, direct selling, serta pemasangan iklan di website jual beli properti dan media sosial. 


\section{Analisis Keuangan dan Pembahasan}

Dalam menganalisis data-data hasil penelitian serta pendekatan asumsi-asumsi, peneliti menggunakan analisis sebagai berikut :

\section{Cash In Flow}

Pada tahun-tahun pertama proyek pembangunan Cluster New City (tahun 2016-2017) di mana telah dilaksanakan tahapan pembelian lahan, aliran uang masuk bersumber utama dari setoran modal pemegang saham. Dan kemudian mulai tahun 2018 dan berikutnya di mana proyek telah memasuki masa konstruksi dan penjualan, aliran uang masuk akan didominasi oleh pendapatan penjualan rumah. Dengan asumsi penjualan rumah sebanyak 60-80 unit per tahun, diproyeksikan akan habis pada tahun ke 8 setelah penjualan dimulai. Proyeksi pendapatan dari penjualan rumah sejak mulai dipasarkan hingga tahun-tahun berikutnya yang dapat dilihat pada tabel proyeksi arus kas.

\section{Cash Out Flow}

Pada tahun-tahun pertama proyek pembangunan Cluster New Rajeg City (tahun 20162017), aliran uang keluar digunakan untuk pembelian lahan, biaya perizinan, dan biaya pengurusan administrasi lahan. Saat penjualan dilakukan aliran uang keluar adalah untuk biaya pemasaran dan promosi, biaya operasional kantor dan proyek, serta biaya konstruksi rumah dan sarana prasarana. Berikut biaya-biaya yang menjadi aliran kas keluar dalam proyek ini.

\section{a. Biaya Pembelian Lahan}

Biaya untuk pembelian lahan ini direncanakan selesai dalam 3 tahun. Dengan asumsi kenaikan tanah pada tahun ke-3 sebesar 28,5 \% berdasarkan angka kenaikan pada tahun sebelumnya. Biaya pembelian lahan dapat dilihat pada tabel proyeksi arus kas.

b. Biaya Perizinan dan Administrasi Lahan

Biaya perizinan dan administrasi lahan ini terbagi menjadi dua tahapan. Untuk tanah induk perizinan dan administrasi lahan harus diselesaikan sebelum proses penjualan dilakukan, sedangkan biaya untuk tanah per unit, biaya dikeluarkan sesuai dengan terjadinya transaksi. Biaya perizinan dan administrasi untuk lahan induk Cluster New Rajeg City dari data yang didapat total biaya sebesar Rp 2.129.080.000,-. Sedangkan biaya untuk tanah per unit dilakukan proyeksi hingga semua unit laku terjual di tahun 2025 dengan asumsi kenaikan biaya sebesar 5\% per tahun. Proyeksi biaya perizinan dan administrasi untuk lahan per unit dapat dilihat pada Tabel 1.

Tabel 1

Biaya Perizinan dan Administrasi Lahan Unit Rumah Cluster New Rajeg City

\begin{tabular}{|c|c|c|c|c|c|c|c|c|c|c|c|c|}
\hline \multirow{2}{*}{ No } & \multirow{2}{*}{ Item } & \multirow{2}{*}{ Total } & \multicolumn{10}{|c|}{ Tahun } \\
\hline & & & 2016 & 2017 & 2018 & 2019 & 2020 & 2021 & 2022 & 2023 & 2024 & 2025 \\
\hline & Rumah Tipe $30 / 60$ & & & & & & & & & & & \\
\hline & Jumlah terjual (unit) & 503 & - & - & 60 & 60 & 80 & 70 & 60 & 60 & 60 & 53 \\
\hline & Unit / lahan tersisa & & 503 & 503 & 443 & 383 & 303 & 233 & 173 & 113 & 53 & - \\
\hline 1 & Biaya Balik Nama per unit & & - & - & 2.000 & 2.100 & 2.205 & 2.316 & 2.432 & 2.554 & 2.682 & 2.817 \\
\hline 2 & Biaya Pengecekan Sertifikat per unit & & - & - & 100 & 105 & 111 & 117 & 123 & 130 & 137 & 144 \\
\hline 3 & Biaya Pembuatan Akte Jual Beli per uni & & - & - & 700 & 735 & 772 & 811 & 852 & 895 & 940 & 987 \\
\hline 4 & Total Biaya balik nama & 1.193 .901 & - & - & 120.000 & 126.000 & 176.400 & 162.120 & 145.920 & 153.240 & 160.920 & 149.301 \\
\hline 5 & Total Biaya Pengecekan sertifikat & 60.402 & - & - & 6.000 & 6.300 & 8.880 & 8.190 & 7.380 & 7.800 & 8.220 & 7.632 \\
\hline 6 & Total Biaya Pembuatan AJB & 418.161 & - & - & 42.000 & 44.100 & 61.760 & 56.770 & 51.120 & 53.700 & 56.400 & 52.311 \\
\hline 7 & PBB unit pecahan sebelum terjual & 255.150 & & & 66.450 & 57.450 & 45.450 & 34.950 & 25.950 & 16.950 & 7.950 & - \\
\hline & Total Biaya & 1.672 .464 & & & 168.000 & 176.400 & 247.040 & 227.080 & 204.420 & 214.740 & 225.540 & 209.244 \\
\hline
\end{tabular}




\section{c. Biaya Konstruksi Sarana Prasarana}

Biaya sarana dan prasarana untuk Cluster New Rajeg City meliputi biaya pembangunan jalan paving blok, pembangunan saluran, pembangunan taman dan children play ground, pintu gerbang dan pos keamanan disertai pagar keliling cluster, balai warga, mushola, jogging track. Selain itu dibutuhkan juga biaya untuk pemasangan listrik dan penerangan lingkungan.Pembiayaan untuk sarana dan prasarana diasumsikan dilakukan dalam jangka waktu dua tahun mengingat volume area yang luas dan fasilitas yang cukup banyak. Pengeluaran biaya sarana dan prasarana untuk Cluster New Rajeg City selama dua tahun adalah sebesar Rp 4.938.434.000,--

\section{d. Biaya Konstruksi Rumah}

Pembangunan konstruksi rumah akan dilakukan secara bertahap. Untuk awal penjualan di tahun 2018, biaya konstruksi rumah adalah sebesar Rp 1.500.000,-/m2. Selain itu terdapat juga biaya pemasangan listrik dan pengeboran sumur pompa untuk tiap unit rumah.Untuk proyeksi biaya konstruksi diasumsikan terdapat kenaikan biaya sebesar $10 \%$ tiap tahunnya. Proyeksi biaya konstruksi untuk proyek Cluster New Rajeg City dapat dilihat pada Tabel 2 di bawah ini.

\section{Tabel 2}

Proyeksi Biaya Konstruksi Rumah Cluster New Rajeg City

\begin{tabular}{|c|c|c|c|c|c|c|c|c|c|c|c|c|}
\hline \multirow{2}{*}{ No } & \multirow{2}{*}{ Item } & \multirow{2}{*}{ Total } & \multicolumn{10}{|c|}{ Tahun } \\
\hline & & & 2016 & 2017 & 2018 & 2019 & 2020 & 2021 & 2022 & 2023 & 2024 & 2025 \\
\hline & Rumah Tipe 30/60 & & & & & & & & & & & \\
\hline & Jumlah terjual (unit) & 503 & - & - & 60 & 60 & 80 & 70 & 60 & 60 & 60 & 53 \\
\hline 1 & \begin{tabular}{|l} 
Biaya Konstruksi \\
Rumah per m2
\end{tabular} & & - & - & 1,500 & 1,650 & 1,741 & 1,837 & 1,939 & 2,046 & 2,159 & 2,278 \\
\hline 2 & \begin{tabular}{|l} 
Biaya Konstruksi \\
Rumah per unit
\end{tabular} & & - & - & 45,0 & 49,5 & 52,2 & 55,1 & 58,2 & 61,4 & 64,8 & 68,3 \\
\hline 3 & $\begin{array}{l}\text { Biaya Pemasangan } \\
\text { listrik per unit }\end{array}$ & & & & 1,650 & 1,815 & 1,997 & 2,197 & 2,417 & 2,659 & 2,925 & 3,218 \\
\hline 4 & $\begin{array}{l}\text { Biaya Pemasangan } \\
\text { sumur pompa per unit }\end{array}$ & & & & 1,500 & 1,650 & 1,815 & 1,997 & 2,197 & 2,417 & 2,659 & 2,925 \\
\hline & Total Biaya & 30.625 & & & 2.889 & 3.178 & 4.483 & 4.151 & 3.767 & 3.987 & 4.221 & 3.948 \\
\hline
\end{tabular}

e. Biaya Operasinal Kantor dan Proyek

Biaya operasional kantor dan proyek meliputi gaji karyawan, biaya keamanan proyek, biaya telepon dan listrik, penyewaan kantor, serta biaya inventaris perusahaan lainnya yang diasumsikan sebesar $8 \%$ dari penerimaan.

\section{f. Biaya Marketing}

Biaya marketing terdiri dari biaya promosi (seperti iklan, stand pameran) dan biaya komisi penjualan tim marketing. Biaya marketing diasumsikan sebesar $4 \%$ dari penerimaan dengan komposisi $2 \%$ biaya promosi dan $2 \%$ komisi penjualan tim marketing.

g. Biaya Pajak

Pajak yang dibayarkan oleh PT. TCM meliputi pajak pembeli (pembelian lahan), PBB, serta pajak pendapatan final sebesar $1 \%$ bagi pengembang perumahan subsidi. 


\section{Proyeksi Cash Flow}

Dari hasil perhitungan, proyeksi arus kas proyek pembangunan Cluster New Rajeg City untuk masa proyek selama 8 tahun dapat dilihat bahwa pada tiap tahun proyek berjalan terdapat peningkatan saldo akhir dan jumlah kas. Dengan jumlah kas pada tahun terakhir sebesar Rp 49.028.572.000,-. Perhitungan proyeksi arus kas dapat dilihat pada Tabel 3.

Tabel 3

Proyeksi Arus Kas Proyek Pembangunan Cluster New Rajeg City

\begin{tabular}{|c|c|c|c|c|c|c|c|c|c|c|c|}
\hline \multirow[b]{2}{*}{ Deskripsi } & \multirow{2}{*}{ Ket } & \multicolumn{10}{|c|}{ Tahun } \\
\hline & & 2016 & 2017 & 2018 & 2019 & 2020 & 2021 & 2022 & 2023 & 2024 & 2025 \\
\hline \multicolumn{12}{|l|}{ CASH INFLOW } \\
\hline 1 Pendapatan dari Penjualan Rumah & & - & - & 8.910 & 9.400 & 13.223 & 12.206 & 11.038 & 11.645 & 12.286 & 11.449 \\
\hline TOTAL CASH INFLOW & & - & - & 8.910 & 9.400 & 13.223 & 12.206 & 11.038 & 11.645 & 12.286 & 11.449 \\
\hline \multicolumn{12}{|l|}{ CASH OUTFLOW } \\
\hline 2 Biaya Perizinan dan Administrasi Lahan Induk & & & 2.129 & - & - & - & - & - & - & - & 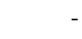 \\
\hline 3 Biaya Perizinan dan Administrasi Lahan per Unit & & - & - & 168 & 176 & 247 & 227 & 204 & 215 & 226 & 209 \\
\hline 4 Biaya Pembangunan Sarana dan Prasarana & & & 2.469 & 2.469 & - & - & - & - & - & - & - \\
\hline 5 Biaya Konstruksi Rumah & & - & - & 2.889 & 3.178 & 4.483 & 4.151 & 3.767 & 3.987 & 4.221 & 3.948 \\
\hline 6 Biaya Operasional Kantor dan Proyek & $8 \%$ & - & - & 713 & 752 & 1.058 & 977 & 883 & 932 & 983 & 916 \\
\hline 7 Biaya Marketing & $4 \%$ & - & - & 356 & 376 & 529 & 488 & 442 & 466 & 491 & 458 \\
\hline 8 Biaya Pajak Penghasilan & $1 \%$ & - & - & 89 & 94 & 132 & 122 & 110 & 116 & 123 & 114 \\
\hline TOTAL CASH OUTFLOW & & - & 4.598 & 6.685 & 4.576 & 6.449 & 5.965 & 5.406 & 5.716 & 6.044 & 5.645 \\
\hline SURPLUS/DEFICIT - OPERASIONAL & & - & $(4.598)$ & 2.225 & 4.824 & 6.773 & 6.241 & 5.632 & 5.929 & 6.242 & 5.804 \\
\hline 9 Biaya Pembelian Lahan & & 3.371 & 7.297 & 867 & & & & & & & \\
\hline NETT CASH FLOW & & (3.371) & $(11.895)$ & 1.358 & 4.824 & 6.773 & 6.241 & 5.632 & 5.929 & 6.242 & 5.804 \\
\hline FINANCING & & & & & & & & & & & \\
\hline 10 Setoran Modal Pemegang Saham & & 3.371 & 11.895 & 6.226 & & & & & & & \\
\hline NET FINANCING & & 3.371 & 11.895 & 6.226 & - & - & - & - & - & - & \\
\hline NET CASH INFLOW & & - & - & 7.584 & 4.824 & 6.773 & 6.241 & 5.632 & 5.929 & 6.242 & 5.804 \\
\hline Beginning Balance & & - & - & - & 7.584 & 12.407 & 19.181 & 25.422 & 31.054 & 36.983 & 43.225 \\
\hline Ending Balance & & - & - & 7.584 & 12.407 & 19.181 & 25.422 & 31.054 & 36.983 & 43.225 & 49.029 \\
\hline Outstanding Loan & & - & - & - & - & - & - & - & - & - & \\
\hline
\end{tabular}

\section{Proyeksi Laporan Laba Rugi}

Pada laporan laba rugi di Tabel 4 terlihat bahwa proyek tersebut akan mulai menghasilkan laba bersih pada tahun pertama berjalan sebesar Rp 1.432.736.000,-. Sedangkan sampai dengan tahun 2025 yaitu setelah 8 tahun beroperasi, proyek tersebut diperkirakan akan menghasilkan laba bersih sebesar Rp 28.154.097.000,-.

\section{Tabel 4}

Proyeksi Laporan Laba Rugi Proyek Pembangunan Cluster New Rajeg City

\begin{tabular}{|c|c|c|c|c|c|c|c|c|c|c|c|c|}
\hline \multirow{2}{*}{ Deskripsi } & & \multirow{2}{*}{ Total } & \multicolumn{10}{|c|}{ Tahun } \\
\hline & & & 2016 & 2017 & 2018 & 2019 & 2020 & 2021 & 2022 & 2023 & 2024 & 2025 \\
\hline $\begin{array}{l}\text { PENDAPATAN } \\
1 \text { Pendapatan dari Penjualan Rumah }\end{array}$ & & 90.157 & - & - & 8.910 & 9.400 & 13.223 & 12.206 & 11.038 & 11.645 & 12.286 & 11.449 \\
\hline Total Pendapatan & & 90.157 & - & - & 8.910 & 9.400 & 13.223 & 12.206 & 11.038 & 11.645 & 12.286 & 11.449 \\
\hline $\begin{array}{l}\text { HARGA POKOK PENJUALAN } \\
1 \text { Biaya Pembelian Lahan }\end{array}$ & & 11.535 & 3.371 & 7.297 & 867 & & & & & & & \\
\hline 2 Biaya Pembangunan Sarana dan Prasarana & & 4.938 & & 2.469 & 2.469 & - & - & - & - & - & - & - \\
\hline 3 Biaya Konstruksi Rumah & & 30.625 & - & - & 2.889 & 3.178 & 4.483 & 4.151 & 3.767 & 3.987 & 4.221 & 3.948 \\
\hline Total HPP & & 47.098 & 3.371 & 9.766 & 6.226 & 3.178 & 4.483 & 4.151 & 3.767 & 3.987 & 4.221 & 3.948 \\
\hline LABA KOTOR & & 43.059 & $(3.371)$ & (9.766) & 2.684 & 6.222 & 8.739 & 8.055 & 7.271 & 7.658 & 8.064 & 7.502 \\
\hline 4 Biaya Perizinan dan Administrasi Lahan Induk & & 2.129 & & 2.129 & - & - & - & - & - & - & - & - \\
\hline 5 Biaya Perizinan dan Administrasi Lahan per Unit & & 1.672 & - & - & 168 & 176 & 247 & 227 & 204 & 215 & 226 & 209 \\
\hline 6 Biaya Operasional Kantor dan Proyek & $8 \%$ & 7.213 & - & - & 713 & 752 & 1.058 & 977 & 883 & 932 & 983 & 916 \\
\hline 7 Biaya Marketing & $4 \%$ & 3.606 & - & - & 356 & 376 & 529 & 488 & 442 & 466 & 491 & 458 \\
\hline & & 14.620 & - & 2.129 & 1.237 & 1.304 & 1.834 & 1.692 & 1.529 & 1.612 & 1.700 & 1.583 \\
\hline LABA SEBELUM BUNGA \& PAJAK BADAN & & 28.438 & $(3.371)$ & $(11.895)$ & 1.447 & 4.918 & 6.906 & 6.363 & 5.742 & 6.046 & 6.365 & 5.918 \\
\hline BIAYA BUNGA & & - & - & - & - & - & - & - & - & - & - & - \\
\hline LABA SEBELUM PAJAK & & 28.438 & $(3.371)$ & (11.895) & 1.447 & 4.918 & 6.906 & 6.363 & 5.742 & 6.046 & 6.365 & 5.918 \\
\hline PAJAK PENGHASILAN & & & & & & & & & & & & \\
\hline 8 Biaya Pajak Penghasilan & $1 \%$ & 284 & (34) & (119) & 14 & 49 & 69 & 64 & 57 & 60 & 64 & 59 \\
\hline LABA BERSIH & & 28.154 & (3.337) & (11.776) & 1.433 & 4.869 & 6.837 & 6.300 & 5.685 & 5.985 & 6.301 & 5.859 \\
\hline
\end{tabular}




\section{Analisis NPV}

Dari proyeksi arus kas didapatkan arus kas bersih atau net cashflow yang digunakan untuk analisis NPV. Dengan discount factor ditentukan sebesar 10\%, hasil analisis NPV didapat hasil positif sebesar Rp 12.061.187.000,-. Nilai positif yang didapat menunjukan bahwa proyek layak untuk dilaksanakan. Perhitungan NPV proyek pembangunan Cluster New Rajeg City dapat dilihat pada Tabel 5.

Tabel 5

Analisis Investasi (Metode $N P V \& P I)$

\begin{tabular}{|c|c|c|c|c|c|c|c|c|c|c|}
\hline \multirow{2}{*}{ Deskripsi } & \multicolumn{10}{|c|}{ Tahun } \\
\hline & 2016 & 2017 & 2018 & 2019 & 2020 & 2021 & 2022 & 2023 & 2024 & 2025 \\
\hline NET CASH FLOW & (3.371.025) & (11.895.047) & 1.358 .108 & 4.823 .770 & 6.773 .436 & 6.241 .138 & 5.631 .617 & 5.929 .189 & 6.241 .744 & 5.803 .978 \\
\hline Discount factor (i) & 1 & 1 & 0,909090909 & 0,8264463 & 0,7513148 & 0,6830135 & 0,6209213 & 0,5644739 & 0,5131581 & 0,4665074 \\
\hline $\begin{array}{l}\text { Discounted Cash } \\
\text { Flow }(P V)\end{array}$ & (3.371.025) & (11.895.047) & 1.234 .644 & 3.986 .586 & 5.088 .983 & 4.262 .782 & 3.496 .791 & 3.346 .873 & 3.203 .002 & 2.707 .598 \\
\hline $\mathrm{NPV}=$ & 12.061.187 & & & & & & & & & \\
\hline $\mathrm{PI}=$ & 1,79 & & & & & & & & & \\
\hline
\end{tabular}

\section{Analisis $P I$}

Dari hasil analisis Profitability Index (PI) untuk proyek pembangunan Cluster New Rajeg City didapat nilai positif sebesar 1,79 . Nilai tersebut menunjukan bahwa PI $>1$ dan berarti proyek layak dilaksanakan. Perhitungan Profitability Index (PI) proyek pembangunan Cluster New Rajeg City dapat dilihat pada Tabel 5 di atas.

\section{Analisis IRR}

Dari hasil perhitungan berdasarkan analisis IRR, didapat nilai sebesar 24,58\%. Angka persentase yang diperoleh menunjukan bahwa proyek pembangunan Cluster New Rajeg City layak untuk dilaksanakan karena memberikan hasil yang lebih besar dari discount factor diinginkan yaitu sebesar $10 \%$. Perhitungan IRR proyek pembangunan Cluster New Rajeg City dapat dilihat pada Tabel 6.

Tabel 6

Analisis Investasi (Metode IRR)

\begin{tabular}{|c|c|c|c|c|c|c|c|c|c|c|}
\hline \multirow[b]{2}{*}{ Deskripsi } & \multicolumn{10}{|c|}{ Tahun } \\
\hline & 2016 & 2017 & 2018 & 2019 & 2020 & 2021 & 2022 & 2023 & 2024 & 2025 \\
\hline NET CASH FLOI & (3.371.025) & (11.895.047) & 1.358 .108 & 4.823 .770 & 6.773 .436 & 6.241 .138 & 5.631 .617 & 5.929 .189 & 6.241 .744 & 5.803 .978 \\
\hline Discount factor & 1 & 0,802685807 & 0,6443045 & 0,5171741 & 0,4151283 & 0,3332176 & 0,2674690 & 0,2146936 & 0,1723315 & 0,1383281 \\
\hline $24,58 \%$ & & & & & & & & & & \\
\hline $\begin{array}{l}\text { Discounted } \\
\text { Cash Flow (PV) }\end{array}$ & (3.371.025) & $(9.547 .985)$ & 875.035 & 2.494 .729 & 2.811 .845 & 2.079 .657 & 1.506 .283 & 1.272 .959 & 1.075 .649 & 802.853 \\
\hline $\mathrm{NPV}=$ & 0 & & & & & & & & & \\
\hline
\end{tabular}




\section{Analisis Payback Period}

Dari perhitungan didapat hasil yaitu waktu pengembalian / payback period untuk proyek pembangunan Cluster New Rajeg City adalah 3 tahun dan 135 hari. Perhitungan Payback Period proyek pembangunan Cluster New Rajeg City disajikan berikut ini.

Data : - Total investment $=\operatorname{Rp} 21.491 .663 .000,-$

Tabel 7

Akumulasi Cash Inflow

\begin{tabular}{|r|r|r|r|}
\hline Tahun & Tahun ke- & Cash Inflow & Akumulasi \\
\hline 2016 & & & \\
2017 & 0 & & \\
2018 & 1 & 7.583 .700 & 7.583 .700 \\
2019 & 2 & 4.823 .770 & 12.407 .470 \\
2020 & 3 & 6.773 .436 & 19.180 .906 \\
2021 & 4 & 6.241 .138 & 25.422 .044 \\
2022 & 5 & 5.631 .617 & 31.053 .661 \\
2023 & 6 & 5.929 .189 & 36.982 .851 \\
2024 & 7 & 6.241 .744 & 43.224 .595 \\
2025 & 8 & 5.803 .978 & 49.028 .572 \\
\hline
\end{tabular}

Dari Tabel 7 di atas dapat dilihat pengembalian investasi terjadi di antara tahun 2020 dan 2021 kemudian dilakukan perhitungan interpolasi linear untuk mendapatkan nilai Payback Period sebagai berikut.

$$
P P=3 \text { tahun }+\frac{25.422 .044-21.491 .663}{25.422 .044-19.180 .906} \times 365 \text { hari }=3 \text { tahun } 135 \text { hari }
$$

\section{KESIMPULAN}

Berdasarkan penelitian terhadap proyek pengembangan Cluster New Rajeg City oleh PT. TCM, maka dari hasil analisis dan pembahasan dapat diambil kesimpulan:

1. Proyek pengembangan Cluster New Rajeg City memiliki nilai investasi sebesar Rp 21.491.663.000,- dan seluruh modal berasal dari pemegang saham. Modal ini digunakan untuk pembelian lahan pengurusan surat-surat serta perizinan. Dan kemudian pada tahun 2018, modal digunakan untuk operasional proyek dan kantor, promosi, serta konstruksi awal sarana prasarana serta bangunan rumah.

2. Dari analisis Payback Period, jangka waktu pengembalian investasi proyek pengembangan Cluster New Rajeg City yaitu selama 3 tahun dan 135 hari.

3. Dari hasil analisis keuangan, proyek pengembangan Cluster New Rajeg City ini layak dilaksanakan oleh PT. TCM. Kesimpulan ini diperoleh dari analisis dan pembahasan sebagai berikut.

a. NPV (Net Present Value) dengan discount factor sebesar $10 \%$ diperoleh nilai sebesar Rp 12.061.187.000,-.

b. Dari hasil perhitungan IRR (Internal Rate of Return) diperoleh nilai sebesar 24,58\% di mana nilai ini yang lebih besar dari discount factor diinginkan yaitu sebesar $10 \%$ (IRR $>10 \%)$.

c. Dari hasil perhitungan Profitability Index (PI) diperoleh nilai sebesar 1,79. 


\section{SARAN}

Dari hasil penelitian terhadap proyek pengembangan Cluster New Rajeg City oleh PT. TCM, beberapa saran yang dapat disampaikan untuk meningkatkan kualitas proyek dan perusahaan yaitu sebagai berikut.

1. Analisis keuangan dengan memperhitungkan nilai waktu uang, proyeksi pendapatan, serta proyeksi biaya penting dilakukan agar dapat memberikan estimasi hasil investasi yang lebih akurat.

2. Penyusunan aliran dana (cash flow) akan sangat menentukan hasil dari analisis keuangan, untuk itu diperlukan ketelitian dan keakuratan dalam mengestimasi dan memberikan asumsi -asumsi pendapatan dan biaya proyek.

3. Studi kelayakan proyek dalam penelitian ini ditinjau dari aspek finansial saja, untuk mendapatkan hasil yang lebih akurat mengenai kelayakan suatu proyek dapat dilakukan penelitian lebih luas dengan meninjau aspek lainnya seperti aspek pasar dan aspek strategi perusahaan.

\section{DAFTAR PUSTAKA}

Badan Pusat Statistik Kabupaten Tangerang. (2016). Distribusi Produk Domestik Regional Bruto (PDRB) Kabupaten Tangerang atas Dasar Harga Berlaku menurut Lapangan Usaha Tahun 2010 - 2016. Retrieved 2017, from BPS Kabupaten Tangerang website : https://tangerangkab.bps.go.id/linkTableDinamis/view/id/7

Badan Pusat Statistik Provinsi Banten. (2016). Laju Pertumbuhan Penduduk Menurut Kabupaten/Kota di Provinsi Banten (persen), 2011 - 2016. Retrieved 2017, from BPS Provinsi Banten website : https://banten.bps.go.id/linkTableDinamis/view/id/71

Badan Pusat Statistik Kabupaten Tangerang. (2016). Kabupaten Tangerang dalam Angka. Banten : BPS Kabupaten Tangerang.

Brigham, Eugene dan Houston, Joel. (2001). Manajemen Keuangan. Jakarta : Erlangga.

Jumingan. 2011. Analisis Laporan Keuangan. Jakarta: Bumi Aksara

Keputusan Menteri Pekerjaan Umum dan Perumahan Rakyat Republik Indonesia Nomor 425/KPTS/M/2015 tentang Batasan Harga Jual Rumah yang Dapat Diperoleh melalui Kredit/Pembiayaan Pemilikan Rumah Sejahtera. (2015).

Sinaga, Dadjim \& Risma, Herlina. (2013). Studi Kelayakan Investasi Pada Proyek dan Bisnis Jakarta : Mitra Wacana Media. 
